Rabaska

Revue d'ethnologie de l'Amérique française

\title{
Les Églises du Québec. Un patrimoine à réinventer
}

Volume 4, 2006

URI : https://id.erudit.org/iderudit/039447ar

DOI : https://doi.org/10.7202/039447ar

Aller au sommaire du numéro

Éditeur(s)

Société québécoise d'ethnologie

ISSN

1703-7433 (imprimé)

1916-7350 (numérique)

Découvrir la revue

Citer ce document

(2006). Les Églises du Québec. Un patrimoine à réinventer. Rabaska, 4, 111-111.

https://doi.org/10.7202/039447ar d'utilisation que vous pouvez consulter en ligne.

https://apropos.erudit.org/fr/usagers/politique-dutilisation/ 


\section{Place publique}

Points de vue / livre

\section{Les Églises du Québec. Un patrimoine à réinventer}

Depuis quelques années, le domaine du patrimoine religieux est l'objet d'un intérêt renouvelé : on voit naître ici et là des études régionales qui tentent de le décrire, on écrit des mémoires et des thèses qui l'approfondissent, on commande des rapports et des études de faisabilité qui accumulent des connaissances nombreuses tandis que les universités analysent le phénomène et l'encadrent dans des centres qui, à leur tour, programment des séminaires, des journées d'études et des colloques dont le rythme va croissant. C'est tout particulièrement le cas des églises du Québec que l'ouvrage récent de Luc Noppen et Lucie K. Morisset paraît marquer d'une pierre blanche. Aussi RABASKA a-t-il confié à deux lecteurs intéressés par ce phénomène la tâche de lui communiquer leurs réactions sur cette importante publication : Richard Gauthier, qui livre le point de vue d'un chercheur québécois, et Jean-Louis Robichaud, qui interprète l'ouvrage à la lumière de son expérience acadienne.

Luc Noppen et Lucie K. Morisset, Les Églises du Québec. Un patrimoine à réinventer, Préface de Jocelyn Létourneau,

Québec, Presses de l'Université du Québec, collection « Patrimoine urbain », 2005, XIX-434 p. ISBN 2-7605-1355-6.

\section{Entre le politique et le symbolique : un débat relevé}

RICHARD GAUTHIER

Stagiaire post-doctoral Chaire de recherche du Canada en patrimoine urbain Université de Québec à Montréal

Pour quiconque se préoccupe du sujet, est maintenant une référence le volumineux livre sur les églises québécoises des historiens de l'architecture Luc Noppen et Lucie K. Morisset, deux spécialistes de la question, bien connus 